ISSN 2078-6441. Вісник Львівського університету. Серія географічна. 2018. Випуск 52. С. 110-123.

Visnyk of the Lviv University. Series Geography. 2018. Issue 52. P. 110-123.

http:/ / dx.doi.org/10.30970/vgg.2018.52.10175

$39: 911.3(=161.2: 1-87)$

\author{
ндрій убик \\ ьвівський н ціон льний університет імені в н \\ вул. . орошенк , 41, 79007, м. ввів, кр їн , \\ e-mail: andriyzubyk88@gmail.com
}

озглянуто суч сний ст н укр їнських ді спор у н ді т . кр їнськ ді спор в цих кр їн х м є пон д столітню історію, з кількістю вон є другою ( н д ) т третьою ( ), після осійської едер ції, у світі. г лом у н ді т прожив $є$ пон д третин від усіх укр їнців поз меж ми н шої держ ви.

нформ ційною основою дослідження ст ли результ ти переписів н селення, які проводили в цих кр їн х, зокрем , їхня етнокультурн скл дов : етнічн н лежність, кр їн походження, рідн мов т мов , якою з звич й розмовляють удом . підсумк ми переписів н селення, які відобр ж ють розселення т етномовну відповідність укр їнців, скл дено вторські к рти в середовищі прогр ми ArcМар. ро н лізов но розселення укр їнської ді спори в розрізі провінцій ( н д ) i шт тів ( ), виявлено зміни в ії розселенні з підсумк ми переписів н селення кінця -поч тку ст., з'ясов но, що в н ді укр їнськ ді спор головно прожив є в тих провінціях, звідки почин л ся укр їнськ емігр ція. змінилось розселення укр їнців: н відміну від поч тку ст., коли укр їнці перев жно прибув ли до шт тів енсильв нія, ью- орк т г йо, н суч сному ет пі вони емігрують здебільшого до шт тів шингтон, регон т ліфорнія.

ході дослідження виявлено, що укр їнськ ді спор в цих кр їн х, попри збереження етнічного походження, з зн л зн чної мовної симіляції. кож простежено територі льну з кономірність етномовної відповідності укр їнської ді спори: чим менш 3 кількістю укр їнськ ді спор , тим вищ етномовн відповідність.

лючові слов : укр їнськ ді спор , симіляція, етномовн відповідність, емігр ція, розселення, рідн мов .

кр їнськ ді спор є однією із н йбільших ді спор у світі. ї формув ння поч лося в ост нній чверті ст. і трив є досі. ричин ми м сової емігр ції укр їнців були і в жке м тері льне ст новище, дві світові війни, політичні т етнічні переслідув ння.

стин укр їнців ст л т к зв ною ді спорою к т клізму через проведення держ вних кордонів після ершої т ругої світових воєн. ізним є досвід прожив ння укр їнців у ді спорі: у деяких кр їн х ( ргентин, р зилія, н д , ) укр їнські ді спори існують пон д 100 років, у кр їн х “нової” трудової мігр ції укр їнці лише почин ють с моорг нізовув тись у ді спори ( реція, т лія, сп нія, ортуг лія). н ді т ді спори є н йст рішими з ч сом утворення. Зн чимо, що вони н й ктивніше підтримують зв'язок з історичною б тьківшиною.

$m$ мет - про н лізув ти дин міку, розселення, етномовну відповідність укр їнської ді спори, ст тево-вікову структуру в розрізі дміністр тивних одиниць середньої л нки н ди т

(c) убик ., 2018 
ем тик укр їнської ді спори недост тньо репрезентов н в н уковій геогр фічній літер турі ост нніх років, нем комплексного дослідження укр їнської ді спори головно в н укових ст ттях. кту льними є дослідження розселення укр їнців у н йбільших кр їн х їхнього розселення ( осійськ едер ція, $\quad$ н д , 3 хст н) тощо. еред н йв жливіших джерел інформ ції про укр їнську ді спору - моногр фічні вид ння . енчук- вличко [15], . буз н [9], . рощинського т . евченк [13], . зебник [8], т пр ця [16]. цих дослідженнях розкрито політичні, соці льно-економічні причини емігр ції з кр їни, под но демогр фічну х р ктеристику укр їнців, які прожив ють поз меж ми кр їни, опис но соціо- т демогеогр фічні процеси в середовищі укр їнської ді спори, про н лізов но зміни в етнічній території кр їни. г лом ці пр ці н водять д ні переписів н селення 1989 р. т оцінні д ні першої половини 90-х років ст

контексті дослідження укр їнських ді спор у н ді т 3 зн чимо про діяльність ентру демогр фічних т соціоекономічних досліджень, відкритого $з$ вдяки ініцітиві мерик нських н уковців укр їнського походження . оловини т . опух . ентр функціонує з 2009 р. при мерик нській філії укового тов риств ім. евченк в . сновними з вд ннями ентру є: збир ти і систем тизув ти н явні ст тистичні д ні про укр їнців у ; полегшити доступ до цих д них дослідник м, політик м, гром дським лідер м; сприяти к демічним т прикл дним дослідженням, що грунтув тимуться н цих д них. пл н х ентру - дод ти інформ цію про укр їнські ді спори в встр лії т н ді [3, с. 171-174].

нформ ційною основою дослідження ст ли етнокультурні критерії прогр м переписун селення н ди т , с ме як: етнічн н лежність, кр їн походження, рідн мов , мов дом шнього спілкув ння.

результ т ми переписів н селення, які проводили в 3'ясов но, що в цих кр їн х прожив є 1209085 т 961113 укр їнців, відповідно (30,2 \% від усієї кількості укр їнців з меж ми кр їни). мігр ція до цих кр їн поч л ся н прикінці ст., коли уряди кр їн поч ли ктивно з охочув ти емігр нтів 3 ентр льної, івденної т хідної вропи. обочу силу емігр нтів використовув ли н промислових об'єкт х, ш хт х, будівництві тощо. ншим н прямом використ ння трудового потенцілу іммігр нтів ст ло фермерство, для чого укр їнцям н д в ли земельні ділянки, т к зв ні гомстеди. ерез зн чну іммігр цію т світову економічну кризу 30-х років ст. поч лося обмеження кількості іммігр нтів 3 пров дженням квот, збільшенням вимог до документів тощо. прикл д, той, хто б ж в емігрув ти до , після отрим ння 3 кордонного п спорт скл д в письмове под ння в мерик нському консульстві. о нього долуч в т кі документи: 1) посвідчення про місце прожив ння впродовж ост нніх п’яти років; 2) свідоцтво мор льності; 3) довідк з місця пр ці бо посвідчення про ф х; 4) свідоцтво про н родження; 5) довідк про медичний огляд лік рями кор бельної лінії. вип дку, коли документи відповід ли вст новленим вимог м, з явник отримув в к рту вступу із з зн ченням д ти прийому в консульстві $\quad$ у рш ві [10, c. 157].

кінця ст. до 1917 р. до цих кр їн емігрув ло 135 000-180 000 т $460000-$ 700000 укр їнців, відповідно. ерез обмеження іммігр ції т н л годження життя в післявоєнній вропі кількість укр їнців, які емігрув ли до н ди т, зменшил сь до 60 000-70000 т 15000-95000 осіб, відповідно. ісля з вершення ругої світової війни сюди емігрув ли укр їнці з т борів для переміщених осіб: у 1945-1991 pp. до н ди емігрув ли 35 000-43 000 осіб, тоді як до $\quad$ - 800 000-120 $000[1,8,13,15,16]$. 
к 6 чимо, до поч тку ругої світової війни емігр ція укр їнців до м совою через лібер льніше іммігр ційне $з$ конод вство. ісля 1945 р. зрост ння укр їнської емігр ції до можн пояснити більшими демогр фічними втр т ми кр їни вн слідок уч сті в ругій світовій війні т ктивній діяльності укр їнських орг ніз цій у , які сприяли емігр ції. окрем , укр їнцям, які прибув ли з т борів для переміщених осіб, н д в ли допомогу з документ ми, житлом т роботою.

н ді укр їнці є однією з н йбільших етнічних меншин, тут прожив є н йбільш укр їнськ ді спор в світі з підсумк ми переписів н селення з фіксов но зрост ння їі кількості (див. т блицю, рис. 1).

озселення укр їнців у н ді з перепис ми н селення поч тку ст. [17]

Ukrainian settling in Canada in early XXI century population censuses

\begin{tabular}{|c|c|c|c|c|c|c|}
\hline \multirow[b]{3}{*}{ ровінція } & \multicolumn{6}{|c|}{ ік перепису н селення } \\
\hline & \multicolumn{2}{|c|}{2001} & \multicolumn{2}{|c|}{2006} & \multicolumn{2}{|c|}{2011} \\
\hline & $\begin{array}{l}\text { кількість } \\
\text { укр їнців }\end{array}$ & $\begin{array}{c}\text { ч стк } \\
\text { від усієї } \\
\text { кількості } \\
\text { укр їнців }\end{array}$ & $\begin{array}{l}\text { кількість } \\
\text { укр їнців }\end{array}$ & $\begin{array}{c}\text { ч стк від } \\
\text { усієї } \\
\text { кількості } \\
\text { укр їнців }\end{array}$ & $\begin{array}{l}\text { кількість } \\
\text { укр їнців }\end{array}$ & $\begin{array}{l}\text { ч стк від } \\
\text { усієї } \\
\text { кількості } \\
\text { укр їнців }\end{array}$ \\
\hline льберт & 285725 & 26,7 & 332180 & 27,4 & 345410 & 27,6 \\
\hline $\begin{array}{l}\text { рит нськ } \\
\text { олумбія }\end{array}$ & 178885 & 16,7 & 197265 & 16,3 & 203585 & 16,3 \\
\hline вебек & 24030 & 2,2 & 31955 & 2,6 & 32245 & 2,6 \\
\hline нітоб & 157660 & 14,7 & 167175 & 13,8 & 174995 & 14 \\
\hline ов отл ндія & 6300 & 0,61 & 7500 & 0,6 & 8520 & 0,7 \\
\hline ун вут & 135 & 0,01 & 290 & 0,05 & 160 & 0,01 \\
\hline ью- $\mathrm{p}$ нсуік & 1970 & 0,2 & 1970 & 0,2 & 3035 & 0,2 \\
\hline $\begin{array}{l}\text { ьюФ ундленд і } \\
\text { бр дор }\end{array}$ & 585 & 0,05 & 945 & 0,08 & 885 & 0,07 \\
\hline HT pio & 290925 & 27,2 & 336355 & 27,8 & 342005 & 27,3 \\
\hline $\begin{array}{l}\text { стрів ринц } \\
\text { дв рд } \\
\end{array}$ & 320 & 0,03 & 780 & 0,06 & 855 & 0,06 \\
\hline $\begin{array}{l}\text { івнічно- хідні } \\
\text { території }\end{array}$ & 1270 & 0,1 & 1445 & 0,1 & 1250 & 0,1 \\
\hline ск чев н & 121740 & 11,4 & 129265 & 10,7 & 136415 & 10,9 \\
\hline ериторія кон & 1520 & 0,1 & 1620 & 0,1 & 1810 & 0,16 \\
\hline н д & 1071060 & 100 & 1209085 & 100 & 1251170 & 100 \\
\hline
\end{tabular}

стк укр їнців від усього н селення н ди в 2011 р. ст новил 3,74\%. рост ння кількості укр їнців з 1981-1991рр. пояснюють підвищенням рівня н ціон льної свідомості етнічних укр їнців. 1981 р. змінилося співвідношення тих, хто н зв в укр їнську н ціон льність як першу т другу. окрем, у 1981 р. 70,1\% укр їнців н зв ли укр їнську н ціон льність як першу, 29,9\% - як другу. 2011 р. ці пок зники ст новили, відповідно, 22,1\% т 77,9\%. к б чимо, з 1981 р. ч стк осіб, які н зив ють укр їнську н ціон льність як першу, зменшується, проте, будучи н щ дк ми від зміш них шлюбів, 
укр їнці в ході перепису н селення з зн ч ють укр їнську як одну зі своїх н ціон льностей. 1996-2001 pр. кількість укр їнців збільшил сь н 4,3 \%, 3 2001-2006 pp. - н 12,9 \%, з 2006-2011 pp. - н 3,5\% (див. рис. 2).

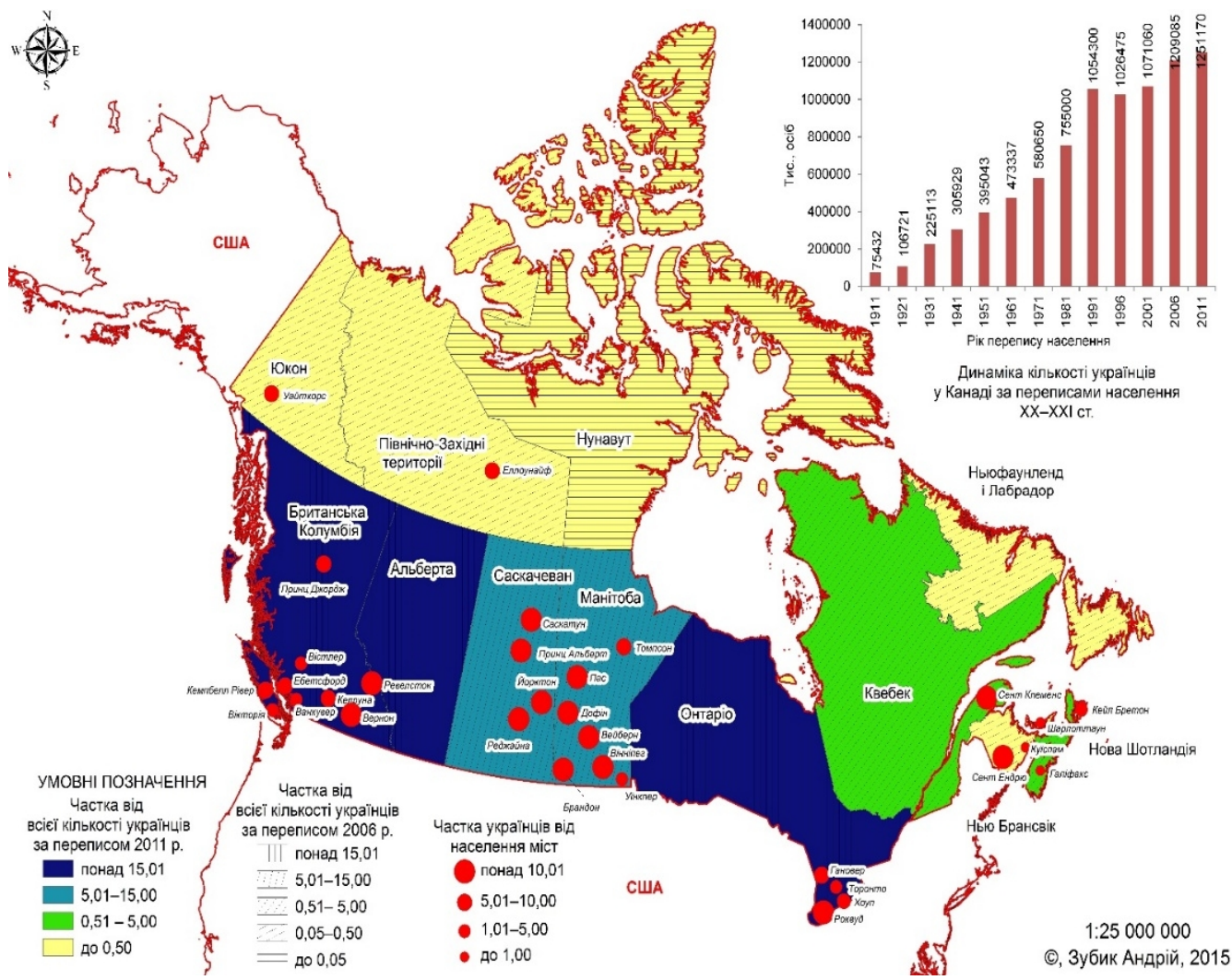

ис. 1. озселення укр їнців у розрізі провінцій н ди 3 перепис ми н селення поч тку ст. [17]

Fig. 1. Resettlement of Ukrainians in Canadian provinces according to the Censuses of early XXI century

н чн ч стк укр їнців прожив є у т ких великих міст х: інніпег $(7,96 \%$ від усієї кількості укр їнців), оронто $(5,1 \%), \quad$ ск тун $(2,85 \%)$, едж йн $(1,94 \%), \quad$ нкувер $(1,45 \%)$ т юррей $(1,33 \%)$. ільше половини укр їнців прожив є у провінціях льберт т нт ріо - 54,9\% від всієї кількості укр їнців у н ді. н чн ч стк укр їнців $€$ у рит нській олумбії (16,3\%), нітобі (14\%), ск чев ні $(10,9 \%)$ т вебеку $(2,6 \%)$, де укр їнці перев жно прожив ють н територіях поч ткового з селення [17]. уковець . втух умовно поділяе укр їнську ді спору в н ді н три групи: )к н дці, які усвідомлюють укр їнське походження т зберіг ють укр їнську ідентичність; б) особи укр їнського походження, які періодично беруть уч сть у діяльності укр їнських орг ніз цій; в) к н дці укр їнського походження, які не виявляють 3 цік вленості щодо укр їнського походження [7, с. 18]. 


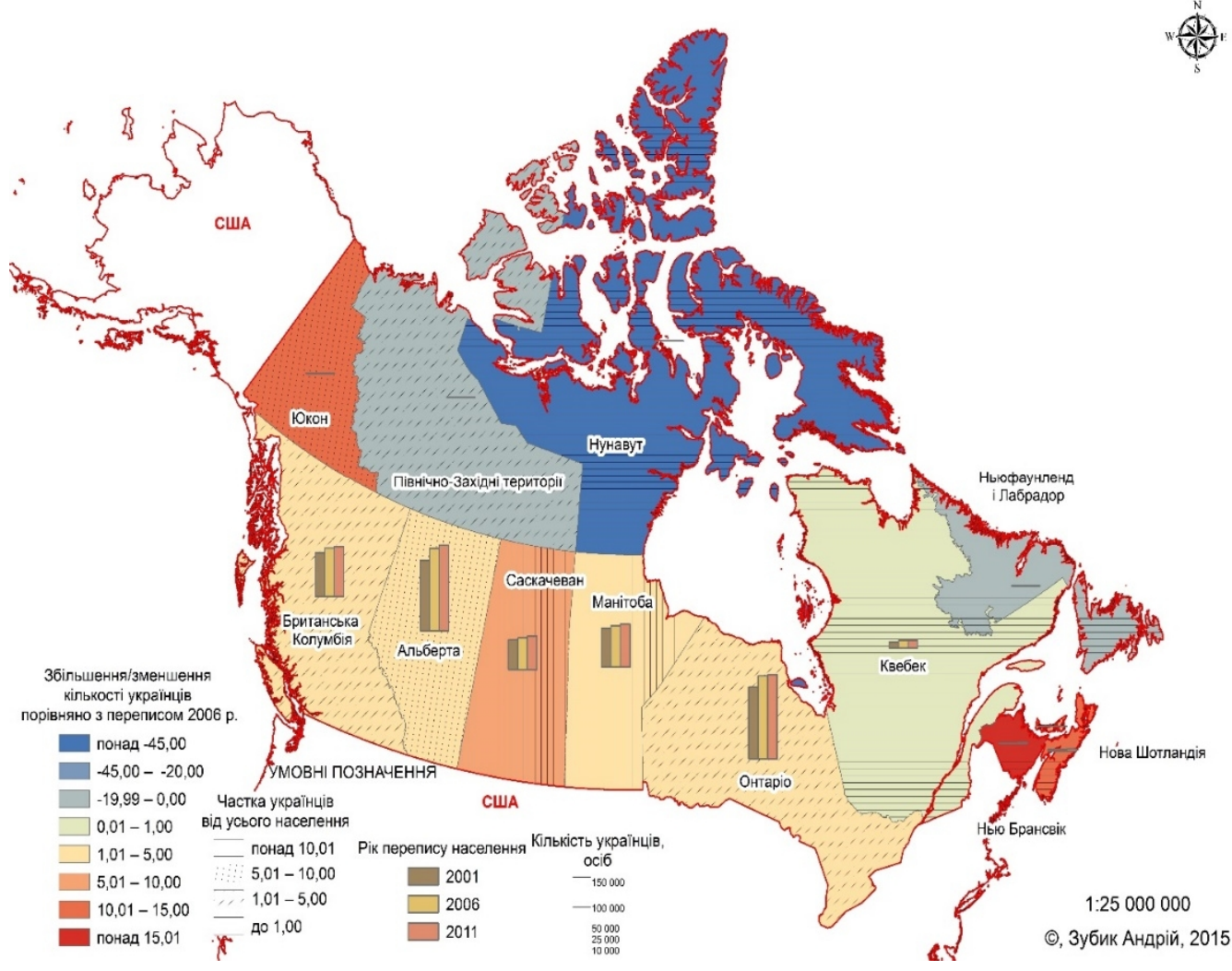

ис. 2. ідносні зміни в кількості укр їнців з перепис ми н селення 2006 і 2011 рр., ч стк укр їнців від усього н селення в розрізі провінцій [17]

Fig. 2. The relative change in the number of the Ukrainian population according to the 2006 and 2011 Censuses, the share of the Ukrainian population in the context of all provinces

вдяки політичній емігр ції, н явності інтелігенції т релігійним гром д м у н ді функціонує велик кількість укр їнських гром дських орг ніз цій (політичних, молодіжних, жіночих т ін.), які з безпечують різном нітні інтереси к н дських укр їнців, м сшт бність т цілісність укр їнської ді спори. ільшість гром дських орг ніз цій об'єдн н в онгрес укр їнців н ди. ут перебув ють т кож викон вчі структури вітового конгресу вільних укр їнців [5, с. 171].

т н і поширення певної етнічної мови зн чно з леж ть від того, скільки ч су вон перебув є в конкретній мовній ситу ції. кр їні з поч тку укр їнської мігр ції минуло пон д 100 років. підсумк ми перепису 2001 р., укр їнську рідною мовою н зв ло 157385 осіб, що ст новить 14,7\% від з г льної кількості укр їнців у кр їні. розрізі провінцій кр їни н йвищою етномовн відповідність укр їнців є у вебеку $(21,3 \%)$, дещо менш - у нітобі $(16,8 \%)$, нт pio $(16,7 \%)$, ск чев ні $(16,1 \%)$, льберті $(11,9 \%)$ т рит нській олумбії $(7,6 \%)$. 
ерепис н селення 2006 р. з фіксув в 141805 укр їнців, які н зв ли укр їнську рідною мовою, що ст новить $11,7 \%$ від всього з г лу укр їнців. орівняно з переписом 2001 р. пок зник зменшився н $3 \%$, що можн пояснити процес ми мовної симіляції, особливостями проведення переписів. йвищою етномовн відповідність укр їнців бул в вебеку (рис. 3) [17]. ерепис 2011 р. з фіксув в 111540 осіб, які н зв ли укр їнську рідною мовою, що ст новить 8,9 \% від з г лу укр їнців.

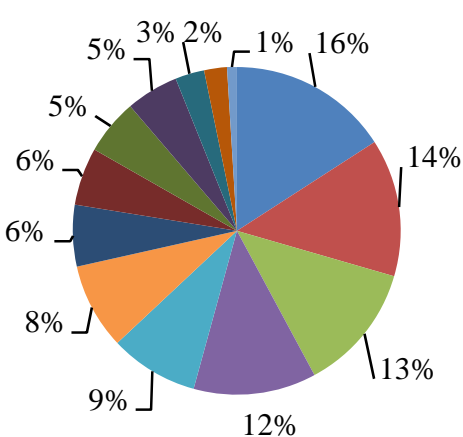

$12 \%$

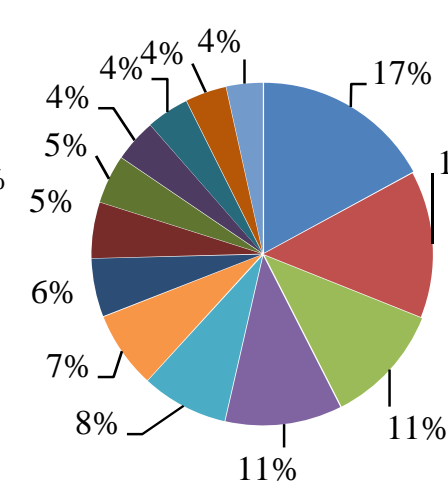

в вебек

- HT pio

- нітоб

с ск чев н

ун вут

- рит нськ олумбія

- ью р нсвік

- івнічно- хідні ериторії

- ов отл ндія

- стрів ринц дв рд

- ьюф унленд і бр дор

- $\mathrm{KOH}$

ис. 3. тномовн відповідність укр їнців у розрізі провінцій

3 перепис ми 2006 і 2011 pp.

Fig. 3. Ethnolinguistic conformity of Ukrainians by the provinces according to the 2006 and 2011 Censuses

езв ж ючи н збереження етнічної ідентичності впродовж перебув ння в кр їні, незн чн ч стк укр їнців н зв л укр їнську рідною мовою. к б чимо, чим більше нових поколінь з'явилося від ч су первинної іммігр ції, тим сильніше симілює укр їнців у мовному спекті домін нтн більшість н селення кр їни.

результ т ми перепису 2011 р., співвідношення ч стки чоловіків т жінок серед укр їнців т осіб укр їнського походження - 48,8 і 51,2 т 48,8 і 51,2 \%, відповідно. іков структур зн чно відрізняється з тими, хто н зв в укр їнську н ціон льність як перше т зміш не походження (див. рис. 4) [17].

кр їні вн слідок трив лості прожив ння т зміш них шлюбів серед укр їнців, які н зв ли укр їнську н ціон льність як першу, незн чною є ч стк осіб віком до 15 років, 15-24 років. ерез зміш ні шлюби дед лі менш ч стк укр їнців у н ступних поколіннях усвідомлює своє етнічне походження. еред осіб, які н зв ли укр їнську н ціон льність як єдину, зн чн ч стк людей ст ршого віку, що свідчить про збереження н ціон льної ідентичності ст ршим поколінням, тоді як нове покоління з зн є симілюв ння.

оч тком м сової емігр ції до вв ж ють 1877 р., коли укр їнці поч ли пр цюв ти н ш хт х у шт ті енсильв нія. кр їнськ емігр ція перших років бул спрямов н до шт тів ью- орк т енсильв нія. огляду н це деякі дослідники схильні вв ж ти їі поч тком м сової мігр ції укр їнців до кр їни. утки про можливість одерж ння вл сних земельних ділянок у поширюв лись кр їною передусім зі лов ччини т К рп ття [8, с. 89]. 


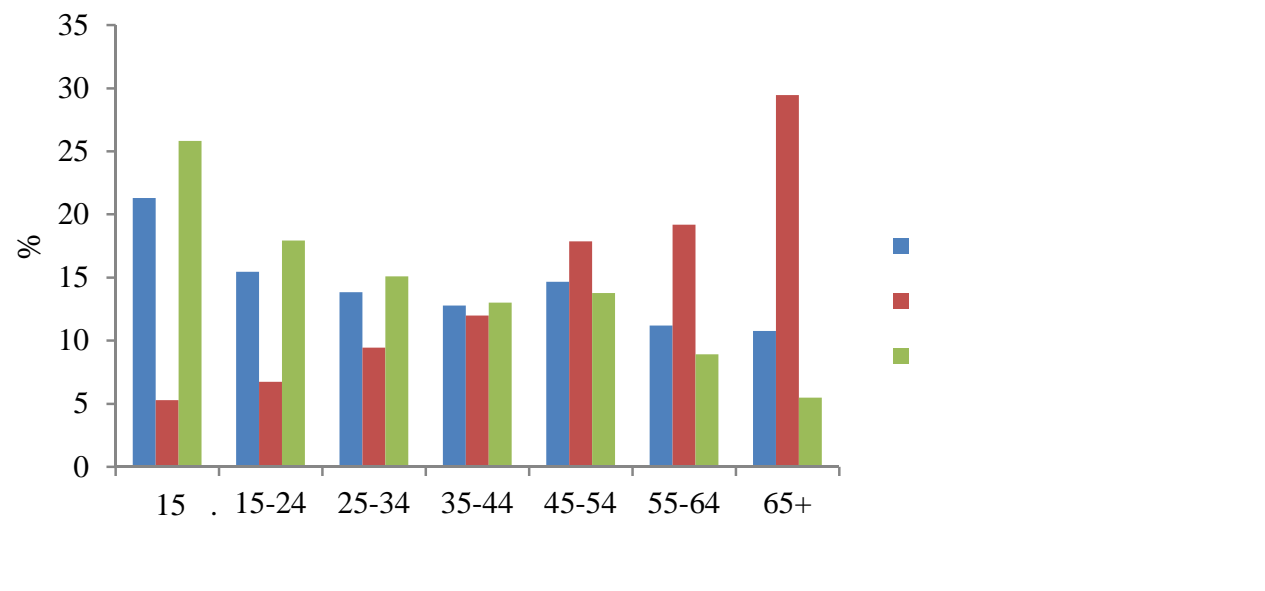

ис. 4. іков структур укр їнців т осіб укр їнського походження

Fig. 4. The age structure of Ukrainians and people with Ukrainian origin

шт т х енсильв нія, ью- орк т ью- жерсі до 1914 р. перебув ло $85 \%$ від усієї кількості іммігр нтів з кр їни [12, с. 17-22]. відміну від н ди, у укр їнські іммігр нти осід ли здебільшого не н ферм х, в міст х і містечк х, пр цюв ли н промислових підприємств х, будівництві т як дом шня прислуг . кр їнці т кож пр цюв ли в сировинній промисловості: добув ли золото і срібло в олор до, онт ні,

йд хо, шингтоні, олово у іссурі, м рмур і в пняк у енсильв нії. н чн ч стин укр їнців бул з діян в мет лургії т мет лообробній г лузях у шт т х ью- орк, енсильв нія, ью- жерсі, ллінойс, н виробництві цементу, мил, п перу і шкіри, н цукрових з вод х, виробництві мил, п перу і шкіри, у спорудженні з лізниць і шляхів, тк цькій т швейній промисловості. е, з одного боку, пояснюв лось н строями тимч совості перебув ння, б ж нням з робити гроші т повернутись н історичну б тьківщину. іншого боку, одерж ння ділянки з помірков ну пл ту потребув ло к піт ловкл день Н помешк ння, сільськогоспод рське зн ряддя т робочу худобу, бсолютн більшість укр їнців т ких коштів не м л [8, с. 90-94].

підсумк ми переписів н селення 1990, 2000 т 2010 pp., у прожив ло 720815,882589 т 931297 укр їнів, відповідно. ост нніми перепис ми н селення, кількість укр їнців у збільшується не лише з вдяки новітній емігр ції, й ун слідок природного приросту. 1990-2000 pр. кількість укр їнців збільшил сь н 161774 осіб (22,4 \%), у 2000-2010 pp. - н 48708 осіб (5,52 \%) (див. рис. 5).

1991 р. кількість укр їнців, які добровільно виїх лиз кр їни з роки нез лежності, м йже вдвічі перевищує кількість біженців у роки після ругої світової війни. 19922011 pр. до $\quad 3$ кр їни іммігрув ло 298474 особи. фіксов но т кі шляхи емігр ції: $1,25 \%$ - емігрув ли до 3 кошти родичів, 4,8-н підст ві укл дених 3 пр цед вцями договорів, 4,45 - шлюбн мігр ція, 3,4 - переїзд до дітей, 1,0 - переїзд до б тьків, 48,3 - скрутне ст новище, 17,3 - з вдяки вигр шу лотерей “Green Card”, 19,5 \% інші причини $[13,18]$. 


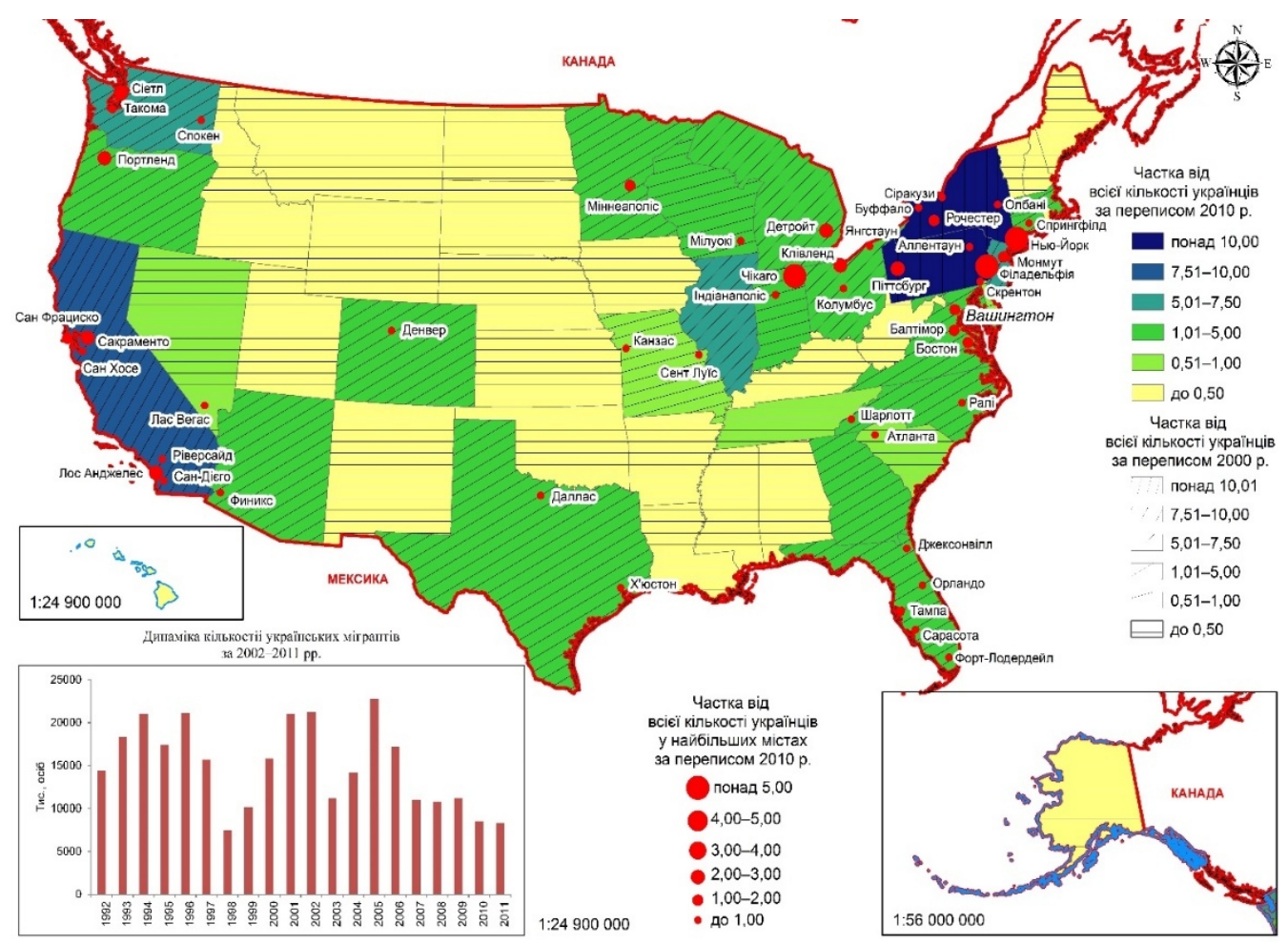

ис. 5. озселення укр їнців у розрізі шт тів

3 перепис ми н селення поч тку ст. [14].

Fig. 5. Resettlement of Ukrainians in the USA according to the Censuses of early XXI century

2010 р. порівняно з підсумк ми перепису н селення 2000 р. кількість укр їнців збільшил сь у шт т х шингтон (п’яте місце, тоді як у 2000 р. - дев'яте), лорид (сьомий з кількістю укр їнців шт т, у 2000 р. - восьмий) т с чусетс (десяте місце, у 2000 р. - один дцяте). переписом н селення 1990 р., рівень урб ніз ції укр їнців ст новив 83,1 \%, з 1990-2000 pр. він зріс до 89,2 \%, перев жно з новоприбулих укр їнських мігр нтів. 16 міст х кр їни 2000 р. прожив ло 59,8 \% укр їнського міського н селення (див. рис. 6) [14].

к ув ж $є$. рощинський, н розвиток укр їнської ді спори вплив ють три чинники: 1) ч стин укр їнців утворил окрему русинську гром ду й не визн є своєї н лежності до укр їнського етносу; 2) ч стин укр їнців приєдн л ся до осійської пр восл вної церкви й відійшл від уч сті в житті укр їнської ді спори; 3) дехто зберіг укр їнську с мосвідомість, одн к підтримув в прор дянські позиції, після проголошення нез лежності кр їни опинився з меж ми орг нізов ного життя укр їнців ерез це суч сн укр їнськ ді спор репрезентує лише ч стину осіб укр їнського походження в цій кр їні. крім історичної п м'яті, лише мов об'єднує укр їнських мерик нців і д є змогу протистояти симіляції [13, с. 62]. 


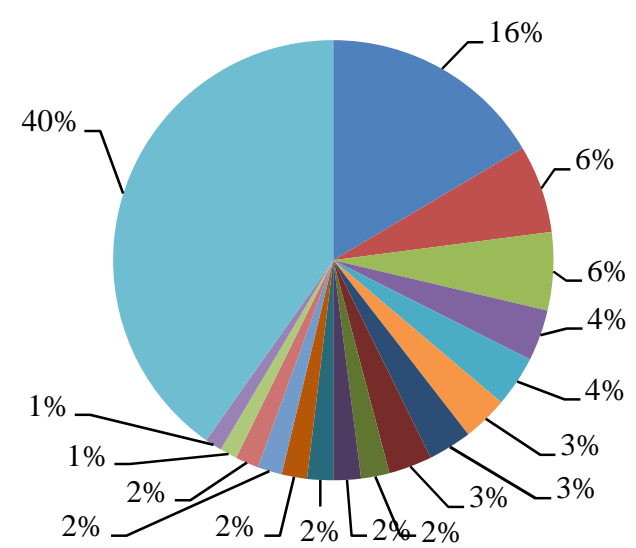

ис. 6. озселення укр їнців у н йбільших міст х

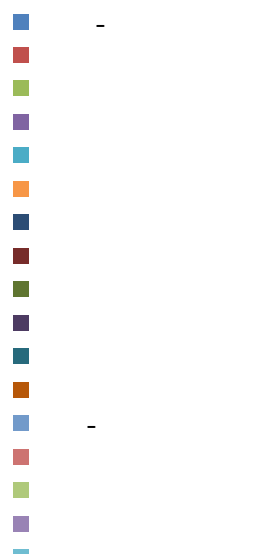

пші міст

3 переписом н селення 2000 p.

Fig. 6. Settlement of Ukrainians in the largest cities of the USA according to the results of the 2000 ensus

перепис ми н селення 2000 т 2010 рр. і демогр фічним дослідженням 2008 р., укр їнську як мову дом шнього спілкув ння н зв ли 14,64, 14,54 т 15,34 \% укр їнців, відповідно. 2008-2010 рр. ч стк укр їнців, які спілкуються укр їнською мовою вдом , зменшил сь, оскільки новоприбулі укр їнські мігр нти ч сто є російськомовними. територі льним розподілом ч стки укр їнців, які спілкуються укр їнською мовою вдом , з фіксов но т ку з кономірність: чим менше кількісне середовище, тим вищ етномовн відповідність укр їнців $[13,18]$.

ільшість укр їнців, які н зв ли укр їнську як мову дом шнього спілкув ння, прожив є у восьми шт т х, тоді як у решті шт тів $-28,3 \%$. осійськ як мов дом шнього спілкув ння поширен в тих с мих шт т х, шо й укр їнськ, 3 винятком г йо (див. рис. 7).

ричин ми т кого співвідношення є комп ктність прожив ння. ерев жно в тих шт т $\mathrm{x}$, де кількість укр їнців незн чн, вони прожив ють в дміністр тивному центрі чи н йбільших міст х. огляду н поліетнічне середовище, у якому прожив ють укр їнці, порівняно незн чн їхня ч стк послуговується укр їнською вдом . появою іммігр нтів “четвертої хвилі" зросл ч стк осіб, які використовують російську мову. Г лом укр їнську т російську як мови дом шнього спілкув ння під ч с перепису н селення 2010 р. н зв ло 29,7 \% укр їнців.

переписом н селення 2010 р., у ст тевій структурі укр їнської ді спори перев ж ють жінки $-51,5 \%$. еред укр їнців, які н родилися у , ч стк чоловіків дещо вищ $-50,12 \%$, тоді як серед укр їнців, н роджених поз меж ми кр їни, перев ж ють жінки -54,95\%. ч сом іммігр ції пон д $80 \%$ укр їнців, які н роджені поз меж ми , іммігрув ли до кр їни у 1988-2010 pp., 13,2 \% - 3 1953-1987, 6,3 - 3 19461952 рр., решт 0,4 \% іммігрув ли до 1946 р. ередній вік укр їнців - 41 рік: для чоловіків цей пок зник ст новить 40,4 року, для жінок - 41,6 року. е підтверджує віков структур укр їнців: $з$ підсумк ми перепису н селення 2010 р., визн чено, що н йвищу ч стку в н селенні ст новлять особи віком 50-59 т 40-49 років - 15,61 т 13,61\%, відповідно [14]. 


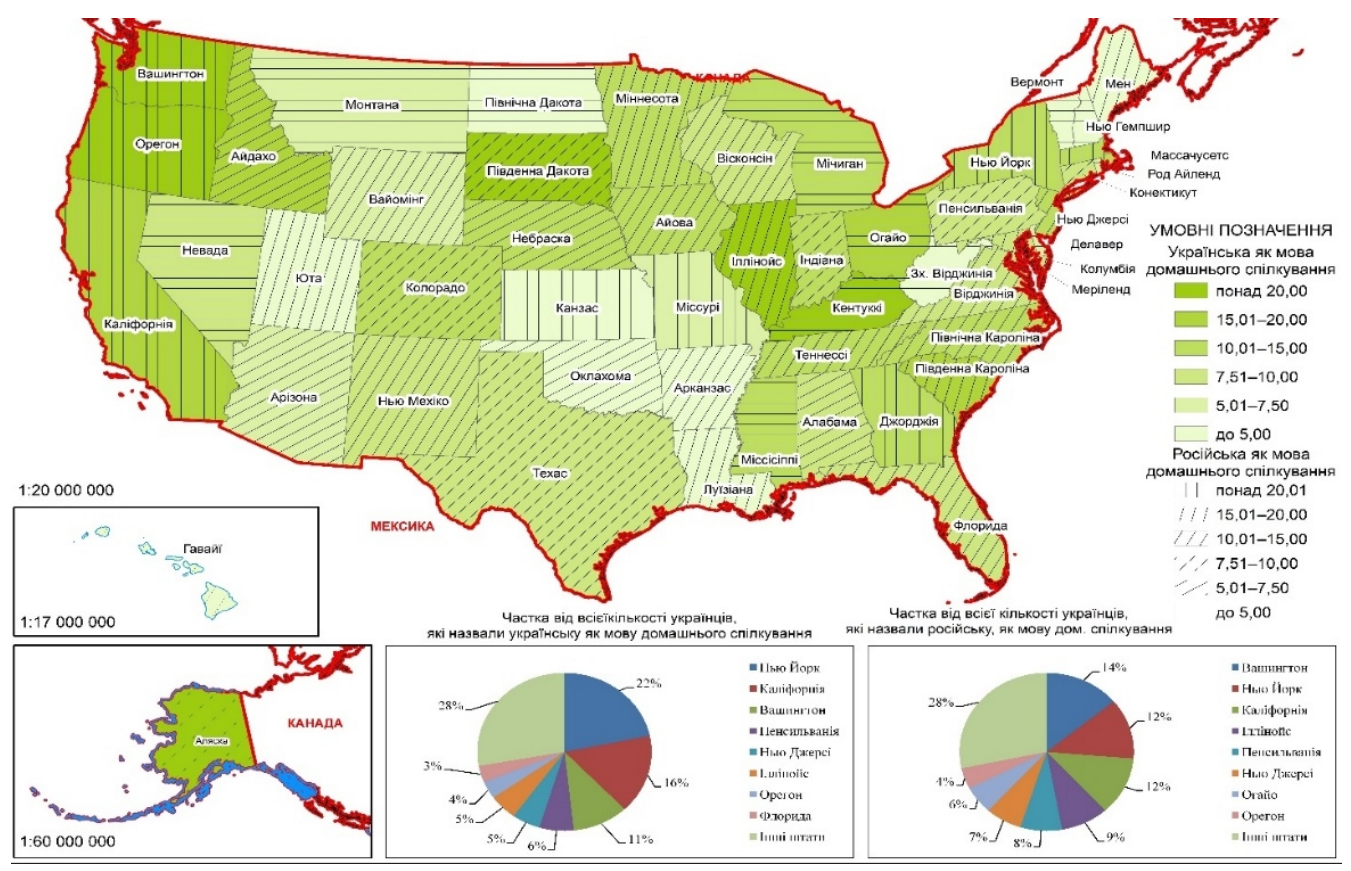

ис. 7. тномовн відповідність укр їнців у розрізі шт тів 3 переписом н селення 2010 p. [14]

Fig. 7. Ethnolinguistic conformity of Ukrainians in the USA according to the results of the 2010 ensus

орівняно з іншими кр їн ми ч стк осіб ст ршого віку є зн чно нижчою. прикл д, ч стк осіб віком 70-79 т 80 років і ст рших ст новить 6,38 т 4,65\%, відповідно. исокою є ч стк дітей т підлітків - 10,66 т $11 \%$, відповідно. ількість укр їнців збільшил сь н 48708 осіб порівняно з д ними перепису н селення 2000 р. ричин ми т кого збільшення ст ли природний приріст т іммігр ція укр їнців до . 33 г льної кількості укр їнців, які прибули до у у 1988-2010 рр., зн чну ч стку ст новили особи віком 25-44 т 45-64 роки - 36,4 т 25,6 \%, відповідно (див. рис. 8).

оширеною інформ цією є володіння житлом. д ними перепису 2010 р., серед 404947 укр їнських домовл сників 69,5\% м ли вл сне житло, 30,5\% - орендов не. ільшість домовл сників $(68,1 \%)$ - укр їнці, н роджені у . еред укр їнців, н роджених у кр їні, 75,9 \% м ли вл сне житло, тоді як серед укр їнців, які н родилися поз меж ми , цей пок зник нижчий - 55,8\%. редст вники “четвертої хвилі” укр їнської емігр ції перев жно орендують житло, хоч зн чн ч стк м є вже вл сне, - 54 т $46 \%$, відповідно [14].

приятливі економічні т демогр фічні чинники зумовлюють збільшення кількості укр їнців у кр їні. гомим джерелом є новітня укр їнськ мігр ція, як оновил вікову структуру укр їнців. ільшість укр їнців м є вл сне житло, проте є відмінності в ч стці тих, хто н родився у $\quad$ т укр їнців, н роджених поз меж ми цієї держ ви. 


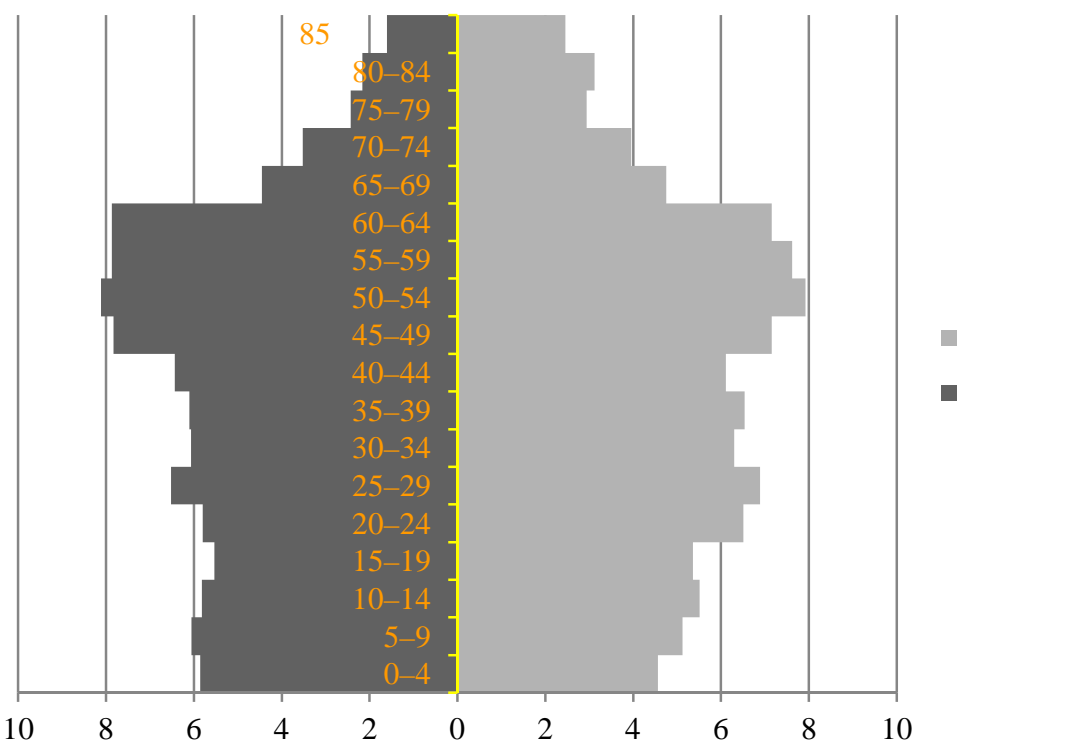

ис. 8. т тево-віков структур укр їнців у 3 переписом н селення 2010 p.

Fig. 8. Sex and age structure of Ukrainians in the USA according to the results of the 2010 ensus

тже, що укр їнські ді спори в н ді т є одними з н йбільших т н йст ріших укр їнських гром д поз меж ми кр їни. ктично з кінця ст. і до сьогодні емігр ція з кр їни в ці держ ви не припиняється. кщо до поч тку ругої світової війни більші мігр ційні потоки укр їнців були спрямов ні до н ди, то після 1945 р. до . кр їнці прожив ють у всіх провінціях і шт т х $\mathrm{H}$ ди т , перев жно селяться у міст х. стк укр їнців у н селенні н ди ст новить $3,74 \%$, тоді як у $-0,3 \%$.

н ді укр їнці здебільшого прожив ють у тих же провінціях, з яких почин л ся укр їнськ емігр ція: нт ріо, рит нськ олумбія т льберт, в зміни в розселенні зумовлені новітнім періодом укр їнської емігр ції, дже новоприбулі укр їнські іммігр нти не поселяються у т ких тр диційних для укр їнців шт т х, як ью- орк т енсильв нія, обир ють міст ушт т х шингтон, регон т ліфорнія як перспективні для пошуку роботи.

езв ж ючи н збільшення укр їнської ді спори в цих кр їн х ун слідок новітньої мігр ції т природного приросту, у середовищі ді спори відбув ються симіляційні процеси, причиною яких є міш ні шлюби.

он д столітня історія перебув ння укр їнських ді спор у н ді т збереженню етнічної ідентичності, одн к відбув ється мовн симіляція. д ними переписів н селення з'ясов но, що порівняно з кількістю укр їнських ді спор їхня етномовн відповідність є низькою. ов “четверт хвиля” укр їнської емігр ції до 
перев жно російськомовн, що вплив є н етномовну відповідність. ьогодні в цих кр їн х уже сформув лися гром дські спільноти, які роблять в гомий внесок у життя історичної б тьківщини, т в суспільне життя кр їн прожив ння.

1. чинський . кр їнськ іммігр ція в получених т т х мерики. иїв, 1995. 342 c.

2. оловин . н ліз д них перепису укр їнців у получених т т х, 1980-1990 pp. // кр їнськ ді спор . 1993. № 4. . 20-30.

3. оловин . укове ов риство ім. евченк в ью- орку проголошує створення дослідницького центру для вивчення укр їнської ді спори в $\quad$ // i спор як чинник утвердження держ ви кр їн у міжн родній спільноті: суч сний вимір, проекція у м йбутнє : ретя міжн р. н ук.-пр кт. конф., м. ьвів, 23-25 червня 2010 р. ьвів : ид-во ьвів. політехніки, 2010. . 175-180.

4. оловин . ові можливості для дослідження укр їнської ді спори в / // i спор як чинник утвердження держ ви кр їн у міжн родній спільноті: суч сний вимір, проекція у м йбутнє: ретя міжн р. н ук.-пр кт. конф., м. ьвів, 23-25 червня 2010 р. ьвів : ид-во ьвів. політехніки, 2010. . 171-174.

5. ністрянський . . тногеогр фія кр їни. ьвів : ид. центр p нк , 2008. 232 c.

6. вmух . . кр їнські к н дці: проблеми соці льно-демогр фічної інтегр ції // кр. істор. журн л. 1991. № 8. . 64-74.

7. вmух . . кр їнці в н ді. иїв : удівельник, 1993.143 с.

8. рубіжні укр їнці / з ред. . . зебник, . . ещенк, . . $\mathrm{k}$ р т iн. иїв : кр їн , 1991. 352 с.

9. буз $н$. . кр инцы в мире: дин мик численности и р сселения. 20-е годы VIII век -1989 год: формиров ние этнических и политических гр ниц укр инского этнос . оскв :

10. ч $б$. мігр ції з з хідної кр їни 1919-1939 рр. ьвів : ид-во ьвів. ун-ту, 2003. $416 \mathrm{c}$.

11. опух . “ ов хвиля” емігр ції до : економічно-соці льні спекти // і спор як чинник утвердження держ ви кр їн у міжн родній спільноті: суч сний вимір, проекція у м йбутнє: ретя міжн р. н ук.-пр кт. конф. м. ьвів, 23-25 червня 2010 р. ьвів : ид-во ьвів. політехніки, 2010. . 65-75.

12. ерфi . . кр їнці в : збереження н ціон льних т культурних тр дицій. онецьк : оулідж, 2010. 247 с.

13. рощинський . . кр їнці в світі. иїв : льтерн тиви, 1999. 352 с.

14. ентр досліджень укр їнської ді спори при уковому ов риству ім. . евченк y [ лектронний ресурс]. URL: www.inform-decisions.com/ukrstat.

15. Lencyk-Pawliczko A. Ukraine and Ukrainians throughout the World: a demographic and sociological guide to the homeland and its diaspora. Toronto : University of Toronto Press, 1994. $509 \mathrm{p}$.

16. Markus V. Ukrainians in the United States // Ukraine. A Consise Encyclopedia. Toronto, 1971. $1300 \mathrm{p}$.

17. Statistics Canada [Electronic resource]. URL: http://www.ssc.ca. 
18. United States Census Bureau [Electronic resource]. URL: http://www.census.gov.

19. Wolowyna $O$. Some consequences of the new wave immigration from Ukraine for the Ukrainian diaspora in the United States // і спор як чинник утвердження держ ви кр їн у міжн родній спільноті: суч сний вимір, проекція у м йбутнє : ретя міжн р. н ук.-пр кт. конф. м. ьвів, 23-25 червня 2010 р. ьвів : ид-во ьвів. політехніки, 2010. . 56-66.

\section{REFERENCES}

1. Bachynskiy, Y. (1995). Ukrainian immigration in the United States of America. Kyiv, 342 p. (in Ukrainian).

2. Wolowyna, O. (1993). Ukrainians census data analyses in the USA, 1980-1990. Ukrainian diaspora, 4, 20-30 (in Ukrainian).

3. Wolowyna, O. (2010). Taras Shevchenko Scientific Community in New York claimed creation of research center to study of Ukrainian diaspora in the USA. Proceedings from Diaspora as a factor of statement Ukraine in international society: modern dimension, projection in future (p. 175-180). Lviv: Publishing house of Lviv Polytechnic University (in Ukrainian).

4. Wolowyna O. (2010). New possibilities for study the Ukrainian diaspora in the USA. Proceedings from Diaspora as a factor of statement Ukraine in international society: modern dimension, projection in future (p. 171-174). Lviv: Publishing house of Lviv Polytechnic University (in Ukrainian).

5. Dnistryanskyi, M. S. (2008). Ethnogeography of Ukraine. Lviv: Lviv University Pub., 232 p. (in Ukrainian).

6. Evtukh, V. B. (1991). Ukrainian Canadians: problems of social-demographic integration. Ukrainian historical journal, 8, 64-74 (in Ukrainian).

7. Evtukh, V. B. (1993). Ukrainians in Canada. Kyiv: Budivelnyk, 143 p. (in Ukrainian).

8. Lazebnyk, S., Leschenko, L., Makar, Y., \& others (Eds.). (1991). Ukrainians abroad. Kyiv: Ukraine, 352 p. (in Ukrainian).

9. Kabuzan, V. M. (2006). Ukrainians in the world: dynamics of number and resettlement $\left(20^{\text {th }}\right.$ years of VIII century - 1989: creation of ethnic and political borders of Ukrainian ethnos). Moscow: Science, 658 p. (in Russian).

10. Kacharaba, S. (2003). Emigration from western Ukraine in 1919-1939. Lviv: Lviv University Pub., 416 p. (in Ukrainian).

11. Lopuph, V. (2010). "New wave" emigration to the USA: social-economic aspects. Proceedings from Diaspora as a factor of statement Ukraine in international society: modern dimension, projection in future (p. 65-75). Lviv: Publishing house of Lviv Polytechnic University (in Ukrainian).

12. Merfi, N. (2010). Ukrainians in the USA: care of national and cultural traditions. Donetsk: Knowledge, 247 p. (in Ukrainian).

13. Troschynskiy, V. P. (1999). Ukrainians in the world. Kyiv: Alternatyvy, 352 p. (in Ukrainian).

14. Center of studying of Ukrainian diaspora at Taras Shevchenko Scientific Community in the USA. Retrieved from www.inform-decisions.com/ukrstat. 
15. Lencyk-Pawliczko, A. (1994). Ukraine and Ukrainians throughout the World: a demographic and sociological guide to the homeland and its diaspora. Toronto: University of Toronto Press, 509 p.

16. Markus, V. (1971). Ukrainians in the United States. Ukraine. A Consise Encyclopedia. Toronto, $1300 \mathrm{p}$.

17. Statistics Canada. Retrieved from http://www.ssc.ca.

18. United States Census Bureau. Retrieved from: http://www.census.gov.

19. Wolowyna, O. (2010). Some consequences of the new wave immigration from Ukraine for the Ukrainian diaspora in the United States Proceedings from Diaspora as a factor of statement Ukraine in international society: modern dimension, projection in future (p. 5666). Lviv: Publishing house of Lviv Polytechnic University (in Ukrainian).

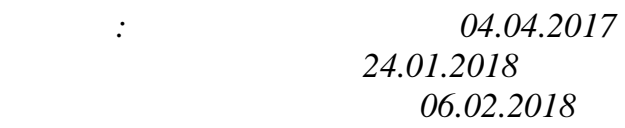

\title{
MODERN UKRAINIAN DIASPORA IN CANADA AND THE USA
}

\author{
Andrii Zubyk \\ Ivan Franko National University of Lviv, \\ P. Doroshenko St., 41, UA - 79007 Lviv, Ukraine, \\ e-mail: andriyzubyk88@gmail.com
}

The current state of the Ukrainian diaspora, which is living in Canada and the United States, is analysed in this article. The Ukrainian diaspora in these countries has more than a century history. It is the second (Canada) and the third (the USA), after the Russian Federation in the world by the number of Ukrainians. More than a third of the total number of Ukrainians outside of our country is overall living in Canada and the United States.

The results of the census conducted in these countries, including their ethnocultural component, ethnicity, country of origin, native language and the language usually spoken at home were information basis of the study. In accordance with the results of the census, which reflect the resettlement and ethnolinguistic conformity of the Ukrainian diaspora, the author maps in the environment of program ArcMap are created. The Ukrainian diaspora resettlement in terms of provinces (Canada) and states (the USA) is analysed in the article. As a result of the late XX-early XXI century census, changes in its settlement is also revealed. It was found that Canadian Ukrainian diaspora lives mainly in the provinces, where Ukrainian emigration had begun. In the US, with the appearance of the fourth "wave" of Ukrainian emigration its resettlement has changed: unlike the early twentieth century when Ukrainians mostly arrived in Pennsylvania, New York and Ohio at present Ukrainians prefer emigration to the states of Washington, Oregon and California.

The study found that the Ukrainian diaspora in these countries, despite the preservation of their ethnic origin, undergo significant linguistic assimilation. According to census found that in Canada and the USA minor ethnolinguistic conformity of the Ukrainian diaspora. The territorial regularity in ethnolinguistic conformity of Ukrainian diaspora: the smaller in number Ukrainian diaspora, the higher ethnolinguistic conformity are traced.

Key words: Ukrainian diaspora, assimilation, ethno-linguistic conformity, immigration, settlement, native language. 